\title{
A Tensão entre Soberania e Instituiç̧ões de Controle na Democracia Brasileira
}

\author{
Leonardo Avritzer ${ }^{1}$ \\ Marjorie Marona ${ }^{1}$ \\ ${ }^{1}$ Universidade Federal de Minas Gerais (UFMG), Belo Horizonte, MG, Brasil. E-mail: \\ avritzer1@gmail.com
}

\begin{abstract}
té bem recentemente, a democracia brasileira apresentava indicadores positivos acerca da sua qualidade ${ }^{1}$, tanto na dimensão procedimental como na dimensão material (Avritzer, 2016). Com respeito à dimensão procedimental, um indicador importante é o fato de que todas as eleições, desde a redemocratização, transcorreram sem fortes questionamentos por parte das forças derrotadas, com exceção da eleição de $2014^{2}$. Ademais, as decisões do judiciário, em especial as do Tribunal Superior Eleitoral (TSE) e as do Supremo Tribunal Federal (STF), sobre eleições e procedimentos correlacionados sempre foram respeitadas pelas diferentes forças políticas (Marchetti, 2013).

Passando da ótica procedimental para a dimensão material, observase que também da perspectiva de resultados a democracia brasileira vinha obtendo êxito. No campo da economia, por exemplo, permitiu que se estancasse a hiperinflação, particularmente pela via da Desvinculação de Receitas da União (DRU) ${ }^{3}$. Por fim, no que diz respeito à inclusão social, a democracia brasileira vinha se destacando positivamente no cenário internacional. O Brasil conta, em 2015, com um coeficiente de Gini de 0,56, menor que o índice apresentado na década de 1990, o que pode ser atribuído à capacidade da democracia brasileira de ampliar o acesso à educação e às políticas de aumento no salário mínimo, e também ao sucesso dos programas de transferência de renda, como o Bolsa Família, por exemplo, que contribuíram para promover maior redistribuição de renda e, consequentemente, mais desenvolvimento (Banco Mundial, 2012).
\end{abstract}

DADOS - Revista de Ciências Sociais, Rio de Janeiro, vol. 60, no2, 2017, pp. 359 a 393.

http://dx.doi.org/10.1590/001152582017123 
Contudo, a conjuntura que se estabeleceu a partir das Jornadas de Junho, em 2013, e se intensificou durante as eleições presidenciais de 2014, estendendo-se até o final do governo Dilma Rousseff em 2016, aponta para um conjunto de desafios que estão postos à democracia brasileira e que pode ser bem apreendido a partir da reconstrução da tensão entre soberania ${ }^{4}$ e controle político, que hoje caracteriza o sistema político brasileiro, e é tributária, em grande medida, da arquitetura constitucional forjada pelo processo de redemocratização e das inovações institucionais agregadas ao sistema de justiça.

De fato, a Constituição de 1988 apresenta um desenho institucional bastante peculiar, que combina intenções de ampliação e aprofundamento da soberania, pela via da participação, com o fortalecimento de instituições de controle político, particularmente atrelada à expansão da linguagem dos direitos e ao fortalecimento das instituições judiciais. A ideia de participação, em princípio, se sobrepõe aos valores mais fundamentais da democracia, como igualdade política e autogoverno, e, no Brasil, a organização da participação popular esteve fortemente vinculada à mobilização da sociedade pela redemocratização do país. No processo constituinte aquele ideário resultou, justamente, na ampliação e aprofundamento da soberania pela via da participação, com destaque para a orientação participativa da Assembleia Nacional Constituinte ${ }^{5}$.

Contudo, ao seu final, a constituinte gerou uma forte institucionalidade participativa que marcou o padrão de participação no Brasil - uma participação em espaços participativos (Abers, 2000; Wampler, 2007, 2014). Os anos 1990 foram, então, marcados por uma explosão da participação social no Brasil no nível local, particularmente nas áreas de saúde e políticas urbanas (Avritzer, 2009). Ademais, a partir de 2003 foram criadas as Conferências Nacionais, as quais já envolveram, até os dias atuais, mais de 6 milhões de participantes, em pelo menos 120 edições.

A estrutura de participação institucionalizada no Brasil se tornou exitosa: implantada inicialmente em algumas cidades, tais como Porto Alegre, Belo Horizonte e São Paulo (Côrtes, 2005), expandiu-se, em poucos anos, para as principais cidades com mais de 100 mil habitantes, nas regiões Sul e Sudeste. Essa estrutura, no entanto, possui vieses, tanto no que toca ao perfil dos atores sociais envolvidos, quanto no que diz respeito às áreas em que se desenvolveu mais fortemente (Côrtes, 2005; Cunha et al., 2011; Vaz, 2014). 
Os impactos distributivos dessa estrutura são mais facilmente demonstrados em algumas áreas do que em outras (Touchton e Wampler, 2014), mas seus impactos sobre o padrão de constituição da representação política eleitoral são de todo mais difíceis de serem apontados. Enquanto inovação institucional (Avritzer, 2009), a participação foi deslocada do seu originário registro popular para um marco cidadão, o que a princípio poderia até mesmo reforçar o marco soberano, se não fosse uma operação paralela de fortalecimento do Poder Judiciário e do Ministério Público, que passou a atuar como mediador da cidadania ${ }^{6}$ (Arantes, 2012), em maior ou menor convergência com ONGs, grupos de interesse e movimentos sociais (Vianna et al., 1999).

A trajetória da proliferação das instituições participativas no Brasil expressa dois importantes deslocamentos no campo, atravessados pelas diretrizes constitucionais, legislação infraconstitucional e mudanças incrementais nos espaços participativos: em primeiro lugar expressa a passagem de um registro popular para um marco cidadão da participação, em tudo compatível com os discursos de deslocamento de legitimidade disseminados pela agenda da judicialização da política; em segundo lugar, denota uma função quiçá complementar da participação em relação à representação.

Enquanto direito, a participação é subsumida pela linguagem liberal da cidadania, tal qual a conforma a Constituição de 1988. Isso vincula a sua plena efetivação à ação estatal e é condizente com a ampliação da linguagem dos direitos (Vianna et al., 1999), resumida no "pacto maximizador" (Vieira, 2008) que o constituinte estabeleceu, e a consequente autonomização do Poder Judiciário e outras instituições do sistema judicial. A convergência entre a expansão da participação cidadã no Brasil democrático e o protagonismo que o Poder Judiciário e o Ministério Público assumiram, particularmente na efetivação dos direitos sociais, difusos e coletivos, apareceu como um movimento bastante bem orquestrado de aprofundamento da democracia brasileira, até pelo menos a primeira década dos anos 2000 .

Por outro lado, a Constituição de 1988 foi produzida a partir de uma percepção generalizada do desequilíbrio histórico entre os Poderes da República, que sempre penderam na direção do Executivo, e da inefetividade das estruturas de checks and balances - o que autorizou Guillermo O'Donnell a desenvolver sua concepção de democracia delegativa (O'Donnell, 1990, 1991, 1996, 1998).

DADOS - Revista de Ciências Sociais, Rio de Janeiro, vol. 60, n’ 2, 2017 
Como contraponto a esta tradição, diversos atores, antes e durante o processo constituinte, propuseram a criação de fortes marcos legais para o fortalecimento da divisão de poderes, da accountability e, nesse mesmo sentido, do judicial review. Destacam-se (1) a garantia de ampla autonomia do poder judiciário (CRFB / 88, arts. 95, 96, 99); (2) o estabelecimento de um complexo e extenso sistema de revisão judicial da constitucionalidade das leis e atos normativos (CRFB/88, arts. 102 e 103); e (3) o reconhecimento e fortalecimento da ampliação das funções do Ministério Público no sentido de fiscalizar políticos e burocratas, aproximando o órgão ministerial da figura das agências burocráticas de accountability horizontal (CRFB/88, art. 127) 7 .

Nesses termos, o marco constitucional, inaugurado em 1988, pode ser apreendido na chave de um reforço da cidadania que passou por um giro na direção da accountability, que não é completamente compatível com a ideia de uma soberania forte, particularmente porque não foi capaz de estabelecer um modelo de controle genuinamente popular, senão que apostou no reforço dos mecanismos internos de controle, o que veio a favorecer, conforme vamos argumentar, uma espécie de pretorianismo judicial (Huntington, 1972), no caso brasileiro ${ }^{8}$. A autonomia gradativamente conferida às instituições judiciais - aqui incluídos o Ministério Público e a Polícia Judiciária, além daquelas que conformam o Poder Judiciário, propriamente - adquiriu contornos de independência, favorecendo uma espécie de pretorianismo sobre as instituições políticas (Avritzer, 2015), que coloca em risco a democracia brasileira.

Temos, assim, um conjunto de rearticulações importantes para a teoria democrática (Rosanvallon, 2009, 2014). De fato, o "giro da accountability" no interior da teoria democrática, a enfatizar o dever de todos os agentes públicos de prestarem contas de seus atos relacionados à aplicação dos recursos, ações e resultados alcançados por políticas, programas e ações propostas e implementadas pelos governos, altera profundamente o tratamento dispensado à questão da legitimidade do sistema político.

Paralelamente ao desenvolvimento de novas ferramentas de gestão deu-se o gradativo fortalecimento das instituições de accountability, o que possibilitou, no caso brasileiro, o desvelar da corrupção, mas também, algumas vezes, denunciou o avanço das instituições de controle sobre a soberania, particularmente as judiciárias, de um modo bastante peculiar. Em parte, pelo modo como a participação avançou na de- 
mocracia brasileira, em parte, pela expansão da linguagem do controle político e seus desdobramentos institucionais, foi operado um deslocamento da problemática acerca da legitimidade da representação política do campo dos impasses da autorização (Almeida, D.; 2010, 2015).

Isso permitiu, por um lado, a ressignificação da participação a partir da proliferação de canais extraparlamentares de representação formal e informal (participação-em-espaços-participativos); e, por outro, da própria representação política, dissociada da ideia de governo representativo, compreendida em sentido alargado como arranjos públicos institucionalizados de larga escala. Contudo, deu asas à pretensão das fortalecidas instituições judiciais (do Poder Judiciário e, particularmente, do Ministério Público) de, ao mediar a cidadania, disputar a representação do interesse público, o que, em um cenário de desvelamento, controle e combate crescentes da corrupção, estabeleceu um quadro de petrorianismo judicial que traz severas máculas à democracia brasileira.

É nesses termos que se encaminha a reflexão acerca da tensão entre soberania e controle político como um dos desafios atuais da democracia brasileira, passando pela retomada da trajetória mais recente do Ministério Público e do Poder Judiciário no sistema político brasileiro, a demonstrar as estratégias de ação de um de outro; mas particularmente chamando a atenção para as inovações institucionais no sistema judicial, as quais permitiram, conforme se argumentará adiante, a formação de um novo padrão de atuação daquelas instituições, nos moldes de um pretorianismo judicial, que coloca em risco o sistema político de um modo geral.

A Operação Lava Jato servirá, no bojo da argumentação que pretendem encaminhar os autores, de substrato empírico exemplar, cientes de que os derradeiros elementos analíticos prescindem, ainda, de um tratamento mais sistemático dos dados. Considera-se, contudo, que o presente texto contribui para as reflexões a que se propõe na medida em que baseado em análises empíricas aponta para uma profunda alteração na agenda da judicialização da política, a incorporar novas problemáticas, principalmente aquelas relacionadas à tensão entre soberania e controle político.

\section{O MINISTÉRIO PÚBLICO E O COMBATE À CORRUPÇÃO NO BRASIL}

O Ministério Público (MP) tem disputado a representação do interesse público ${ }^{9}$ de múltiplas formas em razão do desenho constitucional que emergiu do processo de democratização e, particularmente, das inova-

DADOS - Revista de Ciências Sociais, Rio de Janeiro, vol. 60, nº 2, 2017 
ções institucionais que foram agregadas nas décadas seguintes ao sistema judiciário brasileiro. Contudo, o interesse público, que permite diversas acepções, tem sido tomado a partir do seu elemento exclusivamente republicano, como centrado unicamente no Estado (Habermas, 1987), a despeito das exigências de manifestação da sociedade civil.

A partir da Constituição de 1988, à tradicional função acusatória do Ministério Público, vinculada à sua responsabilidade na propositura da ação penal pública para crimes comuns, foram acrescidas, pelo menos, outras duas funções: (1) a de defensor dos direitos coletivos, difusos e individuais homogêneos, que marcou a sua atuação ao longo dos anos noventa e o alçou à condição de um mediador da cidadania, alargada pelo paradigma constitucional adotado (Arantes, 2002), e (2) a de fiscalizar os políticos e burocratas, o que aproximou o órgão ministerial da figura das agências burocráticas de accountability horizontal, possibiltando que passasse, gradativamente, a disputar a representação do interesse público, conforme já apontado.

Contudo, é importante analisar as relações que o Ministério Público estabeleceu com os demais Poderes da República (Executivo e Legislativo), mas também com as instituições judiciais e judiciárias, particularmente com o Poder Judiciário e com a Polícia Judiciária, diretamente implicadas em uma estratégia de criminalização do combate à corrupção $0^{10}$ - e, em última análise, da atividade política - que lastreia a atual pretensão de representação do interesse público do órgão ministerial. A Figura 1, retirada do sítio eletrônico do Ministério Público Federal é

Figura 1

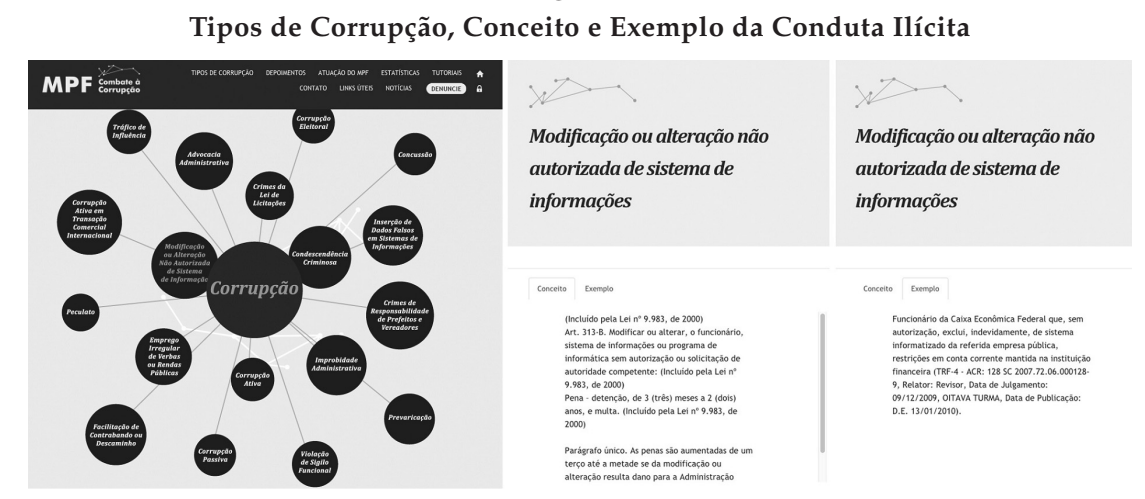

Fonte: MPF (2017). Disponível em http:/ / combateacorrupcao.mpf.mp.br/tipos-de-corrupcao. Último acesso em 3/2/2017. 
bastante ilustrativa do modo como a corrupção é concebida e consequentemente, seu combate judicial é encaminhado.

Note-se que a corrupção é apresentada como uma grande categoria que envolve inúmeras práticas delitivas criminais: com exceção do tráfico de influência (Lei 9.127/95, art. 332), da corrupção eleitoral (Lei $4737 / 65$, art. 299), do crime de responsabilidade de prefeitos e vereadores (Decreto-Lei 201/67, art. 1ㅇ), e da improbidade administrativa (Lei 8429/92, art. 9o), todos os demais crimes listados estão previstos no Código Penal Brasileiro (Decreto-Lei 2848/40), alguns com modificação posterior para ampliação da pena ou do tipo penal. O conceito de cada uma das práticas delitivas é apresentado, com indicação do dispositivo legal, bem como um exemplo do que constitui o crime.

Por outro lado, a atuação do Ministério Público no combate à corrupção se desdobra em ações na área cível, especialmente por meio da ação civil pública e da ação civil de improbidade administrativa, e na área penal, por meio de ações penais públicas, além da possibilidade de atuação, também, no campo extrajudicial ${ }^{11}$. Durante as últimas décadas, o Ministério Público experimentou um desenvolvimento institucional sem precedentes, tendo ampliado sua autonomia funcional, administrativa e financeira, em um processo que, se não se iniciou com a Constituição de 1988, com ela se aprofundou e consolidou (Arantes, 2002; Sadek, 2009; Kerche, 2007; Carvalho e Leitão, 2010) ${ }^{12}$.

Destacam-se duas vantagens institucionais agregadas ao Ministério Público ainda antes do novo marco constitucional, pelo que dispõe a Lei da Ação Civil Pública, de 1985: o Inquérito Civil e a possibilidade de realização de Termos de Ajustamento de Conduta (TAC) ${ }^{13}$. Esses mecanismos foram fundamentais ao longo dos anos 1990 para que o Ministério Público assumisse a posição de mediador da cidadania (Arantes, 2002; 2007), particularmente pela defesa judicial dos direitos sociais, difusos, coletivos e interindividuais, o que possibilitou, também, o avanço do órgão ministerial no campo do combate à corrupção, conformando-o como um órgão de controle político.

Pela via judicial, esse controle pode ser realizado na seara cível ou criminal, a depender do enquadramento do ato como ilícito tipificado pela Lei de Improbidade Administrativa (LIA) ou pelo Código Penal e legislação criminal esparsa, respectivamente ${ }^{14}$. Em um contexto marcado pela morosidade judicial, particularmente pela rigidez do sistema acusatório brasileiro ${ }^{15}$, e pela ineficiência das polícias foi, justa-

DADOS - Revista de Ciências Sociais, Rio de Janeiro, vol. 60, no 2, 2017 


\section{Gráfico 1}

Atuação do Ministério Público (Judicial e Extrajudicial)

(2012-2016)

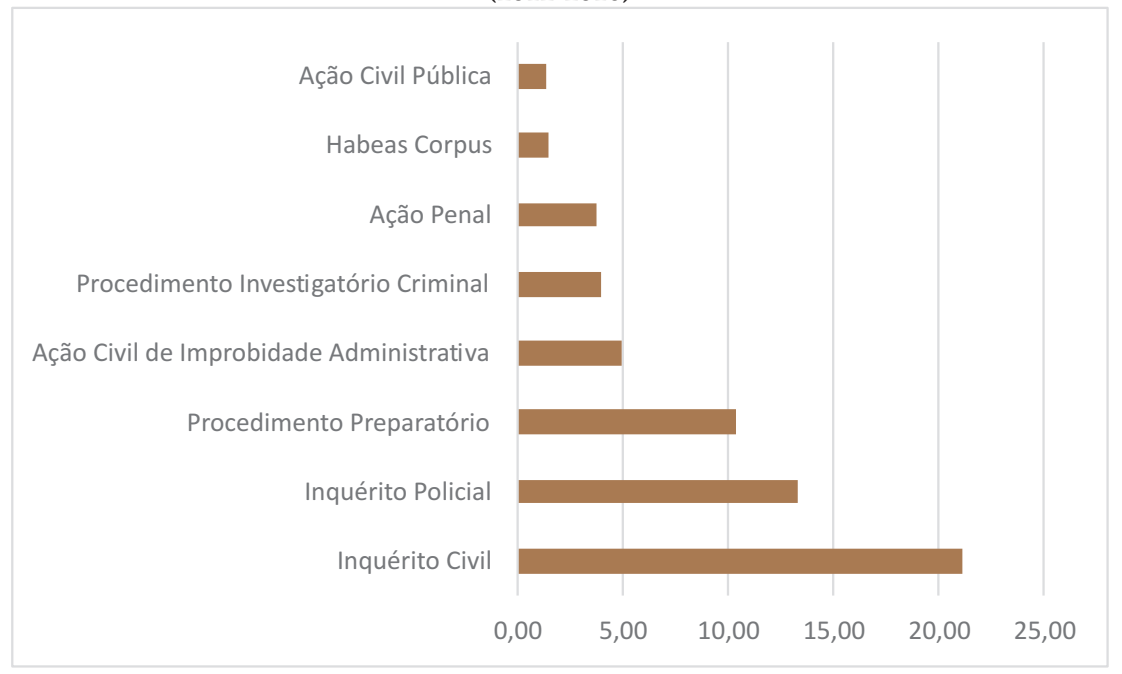

Fonte: Os autores, a partir dos dados do MPF (2017). Disponível em http://combateacorrupcao.mpf.mp.br/estatistica. Último acesso em 3/2/2017.

mente, a investigação civil que permitiu ao Ministério Público ampliar as possibilidades de êxito das suas iniciativas (Arantes, 2015).

A Ação Civil por Improbidade Administrativa responde por 5\% da atuação do MPF, considerando os últimos quatro anos. Já a Ação Penal corresponde a $3,83 \%$ da atuação do órgão ministerial no período. $\mathrm{O}$ Inquérito Civil corresponde a $21 \%$ da atuação do Ministério Público Federal, entre 2012 e 2016, revelando o poder coercitivo do órgão ministerial, que pode requisitar informações e produzir provas por esse meio. Outro importante mecanismo de atuação extrajudicial do Ministério Público, dessa vez na área criminal, o Procedimento Investigatório Criminal, corresponde a $4 \%$ da atuação do parquet. A atuação do Ministério Público em Inquéritos Policiais corresponde a 13\%, o que indica a ação integrada com a Polícia Federal.

De fato, a partir dos anos 2000 a via criminal começou a parecer mais atrativa, particularmente depois da "reabilitação do prestígio do inquérito policial", que veio a reboque do enorme incremento institucional que a polícia judiciária experimentou ${ }^{16}$, particularmente a Polícia Federal ${ }^{17}$ (Arantes, 2010, 2011, 2015) e de inúmeras inovações legais e jurisprudenciais no campo do processo penal basileiro. 
A Polícia Federal ganhou notoriedade, mediante sucessivas autorizações judiciais e sob a fiscalização ou participação do Ministério Público, pelas operações que desencadeou contra políticos corruptos, em todos os níveis da federação e áreas do governo, além de magistrados e policiais de todas as corporações brasileiras e, na esfera privada, empresários, banqueiros e profissionais liberais (Arantes, 2015). Mas ainda que a face policial das operações seja a mais visível, muitas, na realidade, dependem da articulação da polícia judiciária com uma rede de instituições (Arantes, 2010).

De fato, investigação e processamento criminal costumam ser lineares: a Polícia investiga o fato, remetendo ao Ministério Público sua conclusão, o qual, por sua vez, avalia a investigação policial e decide se acusará o investigado - hipótese em que o Poder Judiciário julga o caso. Destarte, o Ministério Público Federal e a Polícia Federal trabalharam de modo integrado: medidas solicitadas à Justiça Federal e operacionalizadas pela Polícia Federal são feitas com o aval e concordância do Ministério Público, do mesmo modo que as atividades dos Procuradores da República contam com a concordância e o apoio da Polícia Federal ${ }^{18}$.

A ampliação das operações integradas da Polícia Federal, em articulação com o Ministério Público, aumentou em muito a eficiência no combate à corrupção e crimes correlatos. Desde 2003 a corporação liderou mais de 2 mil operações contra variados tipos de crime, caracterizadas, basicamente, pela execução de ordens de busca e apreensão e de

Figura 2

Operações Integradas da Polícia Federal (2003-2015)

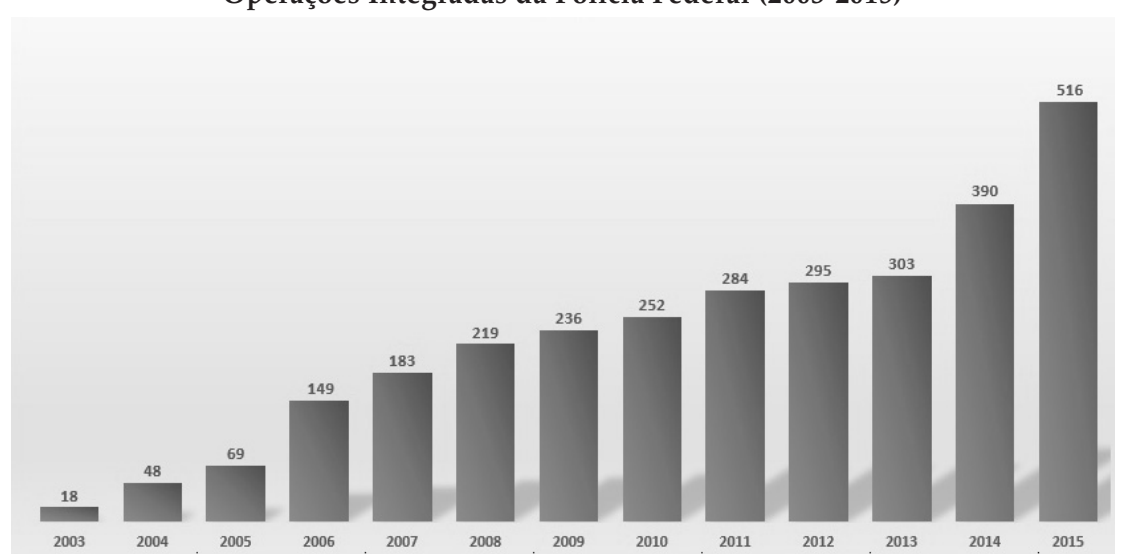

Fonte: Polícia Federal (2017). Disponível em http:/ /www.pf.gov.br/imprensa/estatistica/operacoes. Último acesso em 3/2/2017.

DADOS - Revista de Ciências Sociais, Rio de Janeiro, vol. 60, n² 2, 2017 
ordens de prisão, expedidas pelo Poder Judiciário. Essa ampliação impactou positivamente na percepção de sua legitimidade pública, o que, implicou em ganhos importantes para a instituição ${ }^{19}$. Não restam dúvidas de que a visibilidade que as operações realizadas pela Polícia Federal - Sanguessuga, Hurricane, Rodin - tem alcançado nos últimos anos contribuiu para renovadas representações associadas à instituição.

Contudo, até a deflagração da Operação Lava Jato ${ }^{20}$, em 2014, as investidas investigatórias mais controversas em face das garantias do due process of law $w^{21}$ foram desconstruídas na interseção entre o Supremo Tribunal Federal (STF) e o Ministério da Justiça. A prisão do banqueiro Daniel Dantas, por exemplo, foi duramente criticada pelo então presidente do STF, ministro Gilmar Mendes, que autorizou a sua soltura, em decisão liminar ${ }^{22}$, tendo encaminhado, ainda, denúncia contra o juiz Fausto de Sanctis, responsável pela prisão, ao Conselho Nacional de Justiça, ao Conselho da Justiça Federal e à Corregedoria Geral da Justiça Federal da 3ª Região.

Ademais, a suspeita sobre a ilegalidade de algumas escutas telefônicas suscitou a abertura de inquérito dentro do próprio Ministério da Justiça, o qual serviu de base para o posterior afastamento do delegado da Polícia Federal, Protógenes Queiroz, que comandava a Operação. O que se pretende demonstrar é que, naquele ponto, o próprio campo institucional foi capaz de restabelecer limites à atuação da Polícia Federal - integrada ao Ministério Público e aos órgãos do Judiciário das instâncias inferiores - no âmbito do combate à corrupção, retomando a lógica constitucional-democrática, que envolve o controle político sobre a burocracia, e não tolera as investidas em face dos direitos e garantias fundamentais.

Aquele padrão de interlocução institucional, no entanto, não vem se estabelecendo desde que se instaurou a Operação Lava Jato. $\mathrm{O}$ tratamento dispensado ao tema da responsabilidade política alterou-se fundamentalmente a partir da deflagração da fase ostensiva da Operação Lava Jato, no sentido de uma tendência espécie de pretorianismo judicial, uma adaptação do conceito huntingtoniano. Neste caso, o pretorianismo, isso é, a pressão sobre o sistema político, é exercido por alguns atores do sistema de justiça e das instituições judiciárias que se utilizam da mídia para a ampliação das suas posições (Avritzer, 2015). 
Temos como resultado a criminalização da política, desestabilizando o sistema político de um modo geral.

De fato, pela via criminal, o Ministério Público, em articulação com a polícia judiciária, particularmente a Polícia Federal, e o Poder Judiciário, pelo menos em suas instâncias inferiores - onde a atuação é marcada pela singularidade da jurisdição (uma Vara Judicial = um Juiz Titular) - passou a poder alcançar mecanismos de provas e imposição de custos à reputação dos envolvidos que debilita fortemente o esquema ilegal de atuação, seja pela ruína da base patrimonial dos envolvidos, seja pela privação de sua liberdade, ainda que temporária. Essa via, por outro lado, desafiou a capacidade de articulação entre delegados, promotores e magistrados, no que se refere à requisição, concessão e execução dos procedimentos (Arantes, 2015) e alterou profundamente o sistema judicial de accountability no Brasil, ou, pelo menos, a sua dimensão punitiva.

A questão é que esse processo, do modo como tem sido conduzido, não resulta claramente do fortalecimento institucional do Ministério Público, da Polícia Federal e do Poder Judiciário condizente com o reforço do Estado Democrático de Direito, senão que depende profundamente do protagonismo de determinados atores que, no interior daquelas instituições, assumem estratégias de criminalização do governo e do partido do governo, que deslegitimam, de forma abrangente, o sistema político (Santos, F., 2013).

\section{PRETORIANISMO JUDICIAL E O CONTROLE DO SISTEMA POLÍTICO}

O protagonismo de determinados atores no interior do sistema de justiça está relacionado não apenas com a já referida alteração no padrão de funcionamento dos mecanismos de controle político sobre a burocracia e de controle interno no próprio judiciário ${ }^{23}$, como também, a um processo de jurisprudencialização do direito que se intensificou com o protagonismo das instituições judiciais e que leva a um experimentalismo, particularmente no processo penal, custoso para o ordenamento jurídico de um modo geral e para o sistema político, pelas consequências que avança. Voltaremos a isso nas conclusões do presente texto; por ora, faz-se útil avançar na comprensão do papel do Poder Judiciário.

O alargamento da intervenção do judiciário no âmbito político, que constituiu no Brasil uma nova agenda de pesquisa que opera sobre o conceito de judicialiação da política ${ }^{24}$, por si só, gera desdobramentos so-

DADOS - Revista de Ciências Sociais, Rio de Janeiro, vol. 60, no 2, 2017 
bre as reflexões críticas que avançam no campo da teoria democrática e, particularmente, da teoria da representação (Pogrebinschi, 2011). Aqui interessa, contudo, a relação bastante particular entre o apontado protagonismo das instituições do sistema de justiça e judiciárias no campo da responsabilidade política e a tendência de criminalização dos comportamentos políticos.

As estratégias de criminalização da atividade política levadas a cabo no interior do sistema de justiça no Brasil, envolvem deslocamentos conceituais importantes, que merecem aqui ser destacados, particularmente pela introdução de institutos jurídicos e concepções teóricas forjados alhures. Comecemos por uma breve reflexão acerca do instituto da delação premiada, um mecanismo do Direito Penal, típico em sistemas de common law, e que se fortalece sob a retórica das dificuldades enfrentadas pelo Estado na punição dos crimes praticados em concurso de agentes, em face do aumento e da sofisticação da criminalidade ${ }^{25}$.

A delação premiada é um instituto vinculado ao modelo jurídico anglo-saxão, respaldado no pressuposto de que a participação do infrator com a administração da justiça penal constitui um dos pilares para efetiva prestação jurisdicional do direito de punir, o que favorece as práticas negociáveis no âmbito jurídico penal e processual penal. Neste caso, o modelo da delação premiada é a ideia do direito como barganha contratual (Scott e Stuntz, 1992). Aí a delação premiada existe como um meio de apresentar resultados práticos à sociedade.

De fato, o sistema criminal de justiça norte-americano, na atualidade, guarda pouca relação com aquilo que os Founding Fathers preceituaram e que tinha no júri popular seu elemento crítico, não apenas porque servia como um mecanismo de busca da verdade e um meio de realizar a justiça, mas também por operar como uma proteção contra a tirania ${ }^{26}$. Tensionando, inclusive, com o que preceitua a Sexta Emen$\mathrm{da}^{27}$, o sistema de justiça criminal norte-americano é quase exclusivamente um sistema de negociação de culpa ${ }^{28}$, realizada a portas fechadas e sem supervisão judicial, sendo o resultado amplamente determinado pelo promotor, responsável pela acusação.

As críticas mais importantes dirigidas a esse sistema dizem respeito, justamente, a desvantagem informacional da defesa em relação à acusação, a excessiva rigidez e severidade das leis penais, particularmente no que diz respeito à dosimetria da pena, a ausência de controle (interno e externo) sobre a atuação estratégica da acusação (promotoria), 
o que afeta frontalmente a natureza negocial do plea bargain, particularmente o pressuposto de autonomia das vontades e equidade entre as partes envolvidas (Rakoff, 2014).

Sob a influência da experiência norte-americana (Wacquant, 2001), o instituto vem sendo adotado no Brasil a partir da edição da Lei dos Crimes Hediondos ( $\mathrm{n}-8.072 / 90)$, passando a integrar outras numerosas legislações, tais como a Lei dos Crimes Contra a Ordem Tributária (no 8.137/90), a Lei do Crime Organizado (no 9.034/95), a Lei de Lavagem de Dinheiro (no 12.683/12), e, finalmente, a Lei de Organizações Criminosas (no 12.850/13). Importante observar que a evolução do instituto pode ser inserida em uma estratégia mais vasta de promulgação de leis penais de emergência ${ }^{29}$, que criam um sistema penal cuja finalidade primordial é atender ao clamor popular, e que opera no âmbito de instituições judiciais altamente seletivas, conforme apontaremos.

Se, num primeiro momento, a delação premiada esteve restrita ao crime de bando ou quadrilha, cuja finalidade era estimular por meio de uma redução na pena corporal a denúncia por parte dos membros daquela com o fito de permitir o desbaratamento da quadrilha, gradativamente foram sendo ampliadas não apenas as vantagens (penais e processuais) e garantias (de proteção por parte do Estado) concedidas aos delatores, como também o seu âmbito de aplicação, que culminou em uma sistematização detalhada do instituto.

Há, portanto, requisitos específicos da delação premiada no direito brasileiro: a colaboração espontânea; a participação do delator na prática da infração; a relevância nas declarações; e a efetividades das informações. Desse modo, nota-se que o instituto da delação premiada no direito brasileiro não permite, em princípio, tão ampla negociação com o criminoso, tal como ocorre no direito americano, em que o Ministério Público tem extensa liberdade para isso. O procedimento completo, regulamentando o instituto, foi previsto apenas pela Lei $12.850 / 2013$, que apresenta medidas de combate às organizações criminosas: os benefícios variam de perdão judicial, redução da pena em até dois terços e substituição por penas restritivas de direitos, exigindo-se, conforme já apontado, que a colaboração seja voluntária e efetiva (art. $\left.4^{\circ}\right)$.

O benefício oferecido é dependente, portanto, do resultado alcançado, que pode ser a identificação de cúmplices e dos crimes por eles praticados, a revelação da estrutura e funcionamento da organização crimino-

DADOS - Revista de Ciências Sociais, Rio de Janeiro, vol. 60, n’ 2, 2017 
sa, a prevenção de novos crimes, a recuperação dos lucros obtidos com a prática criminosa ou a localização de eventual vítima com sua integridade física assegurada. Em princípio, assim como no sistema norte-americano ${ }^{30}$, o juiz não deve participar das negociações para formalização do acordo de colaboração, entretanto é responsável por homologá-la, depois de aferidos critérios formais estabelecidos pela legislação. Vale lembrar, ainda, que é o juiz quem preside o processo, de sorte que a avaliação acerca da efetividade da colaboração vincula-se ao desiderato por ele moldado na condução dos casos que julga.

No Brasil, o inquérito policial, que é atividade específica da polícia judiciária (CRFB/88, art. 144), isto é, Polícia Civil (âmbito da Justiça Estadual) e Polícia Federal (Justiça Federal), tem por objetivo a apuração das infrações penais e de sua autoria (Código de Processo Penal, art. $\left.4^{\circ}\right)$. Nessa fase investigatória, de natureza administrativa e realizada anteriormente à provocação da jurisdição penal, o juiz intervém para tutelar violações ou ameaças de lesões a direitos e garantias das partes, podendo exercer atos de natureza jurisdicional, somente quando provocado e resguardando a efetividade da função jurisdicional ${ }^{31}$. Os mandados de busca e apreensão, interceptações telefônicas, ou qualquer invasão das inviolabilidades constitucionais (direito à honra, à imagem, à privacidade), dependem de ordem judicial.

A colaboração premiada, por expressa determinação legal (art. 3ํ, I, da Lei no 12.850 /13), é um meio de obtenção de prova, assim como o são a interceptação de comunicações telefônicas ou o afastamento dos sigilos financeiro, bancário e fiscal (incisos IV a VI do referido dispositivo legal). Isso significa que a colaboração premiada, por si, não constitui fonte de convencimento judicial, mas, ao contrário, constitui um instrumento para a colheita de elementos ou fontes de provas, estes sim, aptos a convencer o julgador ${ }^{32}$.

Mas é possível garantir a imparcialidade do juiz no curso da ação penal, uma vez que atuou na fase de investigação, quando se realiza a produção das provas preliminares? Dentre as vedações expressas do art. 252 do CPP não consta qualquer menção à atuação do juiz na fase de investigação, o que significa - considerando que o STF (Habeas Corpus no 92.893/ES, Rel. Min. Ricardo Lewandowski, DJ de 12/12/08) já se manifestou no sentido de que se trata de rol taxativo - que ele poderá (e por vezes deverá, segundo regras de determinação da competência) atuar na fase judicial ${ }^{33}$. 
Há que se considerar que um dos princípios a nortear o sistema acusatório brasileiro é o do devido processo penal (due process of law), que sintetiza aquele vasto catálogo de direitos fundamentais, previstos na Constituição de 1988, os quais representam um compromisso ético entre Estado e sociedade. As normas penais infraconstitucionais possuem, consequentemente, uma estreita relação com aqueles direitos e garantias fundamentais e, por isso mesmo, desempenham um importante papel na concretização do princípio do devido processo legal. Daí que a discussão acerca do instituto da delação premiada - mecanismo processual, de base legal - deve estar inserida no contexto normativo imposto pela Constituição de 1988, de respeito e garantia dos direitos fundamentais e, particularmente, de atenção ao princípio do devido processo legal.

As princípais críticas dirigidas ao instituto da delação premiada orbitam em torno de duas dimensões: (1) uma abstrata, que aponta para a tensão que o instituto estabelece com direitos e garantias fundamentais do indivíduo, não apenas porque viola o direito constitucional do cidadão de não ser obrigado a fazer prova contra si mesmo, mas também porque flexibiliza o caráter de indisponibilidade da ação penal, permitindo-se que o Estado negocie o seu papel de interdição e aplicação da lei penal; e (2) uma dimensão concreta, vinculada a falta de critérios e limites para sua utilização, embasando decisões consequencialistas que podem vir a suprimir o processo judicial e suas garantias pela aceleração procedimental dos espaços de consenso, pois ao permitir que o órgão acusatório negocie a pena com o cidadão investigado viola-se o pressuposto fundamental da jurisdição, já que a violência repressiva da pena não passa mais pelo controle jurisdicional (Streck, L., 2013; Lopes Jr., 2002, 2011).

Isto é, a validade e legitimidade da delação premiada estão vinculadas, de forma indelével, pelos modos de aplicação da medida e justamente por isso é preciso compreender que a criminalização do combate à corrupção, que marca a atuação recente do Poder Judiciário em face da judicialização da política está inserida em um jogo político - provavelmente imperceptível sob o pano de fundo de um contexto institucional em que as pessoas não são eleitas e, sim, sobem na carreira, a princípio, por mérito.

Em um cenário de fortalecimento das instituições do sistema de justiça, o direito penal afasta-se dos princípios constitucionais e normas le-

DADOS - Revista de Ciências Sociais, Rio de Janeiro, vol. 60, nº 2, 2017 
gais - a anunciada ausência de criteriologia, substituída por um experimentalismo jurisprudencial centrado na figura do juiz. Isso em um contexto em que claramente existe "uma política entre grupos de juristas influentes para formar alianças e disputar espaço, cargos ou poder dentro da administração do sistema" (Almeida, F., 2010). Nesses termos, o juiz, longe de assumir uma postura de omissão ou pretensão de apoliticidade, visa, positivamente, à legitimação da aplicação intensiva do direito penal e à sua promoção, postura que justifica nas bases de discurso de realidade, revelada seja pela histórica impunidade ou pela morosidade do Poder Judiciário (Falcão, 2015).

\section{PRETORIANISMO JUDICIAL E CONTROLE POLÍTICO NO BRASIL}

Essa postura desloca a base de legitimidade da atuação judicial do campo da independência para o da popularidade, em adesão a um campo majoritário contingencial. Da independência judicial, duramente construída ao longo do processo constituinte e de redemocratização dá-se um salto ao pretorianismo judicial (Avritzer, 2015), o que revela, pelo menos duas importantes questões no que toca ao sistema de controle político, no Brasil: (1) uma tendência à desinstitucionalização, pois o sistema de controle passa a operar na base de uma substituição dos remanescentes déficits de interação e controle pelo protagonismo pessoal de alguns atores (Marona, 2015); e (2) uma tendência à seletividade, que acompanha as clivagens do Poder Judiciário e, também, da classe política. Essas duas questões estão intimamente vinculadas e se articulam, de modo penoso para a democracia brasileira, diante de um contexto de baixa representatividade do sistema político e da ausência de mecanismos de controles políticos institucionais sobre a burocracia e de controles internos ao próprio sistema judiciário.

O déficit de autonomia do qual o Judiciário e as instituições de controle no Brasil historicamente padeceram foi sanado, particularmente pelo reforço da autonomia do Poder Judiciário e do aprofundamento e extensão do sistema de controle judicial de constitucionalidade (CRFB / 88, arts. 95 e 96, 102 e 103), o que permitiu que o Judiciário passasse a exercer mais amplamente as suas prerrogativas, tal como o sistema de pesos e contrapesos exige. Ao mesmo tempo, o Ministério Público, por meio do que dispõe o artigo 127 da Constituição, inicialmente ampliou sua atuação no campo dos direitos difusos e coletivos e, avança, hodiernamente, no combate à corrupção, pela via criminal. Por fim, as mudanças na Polícia Federal a partir de 2004 comple- 
taram a reforma das instituições judiciárias de controle com uma polícia judiciária aparelhada e com capacidade operacional.

Como resultado, o padrão de judicialização da política se alterou, profundamente: passou-se da esfera cível de atuação para a criminal, do aprofundamento de um projeto inclusivo, pela efetivação de direitos difusos e coletivos, para uma preocupação com o controle e combate da corrupção, realizado, atualmente, sob as suspeitas de inúmeras violações de direitos e garantias individuais. A politização do Judiciário tornou-se seletiva, embalada pela redução da concepção de interesse público à institucionalidade, em um âmbito - o judicial - que padece de um profundo insulamento.

A questão aqui é que a concepção de interesse público, reduzido ao seu aspecto republicano, centrado no elemento estatal, tem privilegiado, na prática, um padrão de operação das instituições do sistema de justiça e judiciárias, pelo menos no âmbito do controle, fundado em uma gramática de insulamento das instituições do sistema judicial em relação à soberania popular. Este insulamento é nefasto para a democracia brasileira, porque tensiona a soberania e estabelece uma disputa no campo da representação política que "configura curiosamente um paradoxo de legitimidade, pois, de um lado, as formas de representação extraparlamentar" - pretensamente resolvidas pela linguagem do accountability - "acusam implícita ou explicitamente limites na representação eleitoral, mas, de outro lado, não possuem mecanismos próprios claros ou aceitos capazes de alicerçarem sua própria legitimidade" (Lavalle e Vera, 2011:127).

O custo para a democracia brasileira é a redução da sua dimensão soberana. O risco, o estabelecimento de um padrão de operação das instituições judiciárias, pelo menos no âmbito do controle, fundado em uma gramática de insulamentodo jurídico em relação ao político. Assim, se estabelece uma disputa em relação à pretensão de representação política exercida por aquelas instituições.

Nesses termos, a dimensão repressiva de combate à corrupção, tende a dar tratamento criminal à atividade política, a partir de um conjunto de estratégias que envolvem deslocamentos conceituais e procedimentais, concretizados no uso particular que fazem aqueles atores de determinados institutos jurídicos, designadamente no âmbito da Operação Lava Jato.

DADOS - Revista de Ciências Sociais, Rio de Janeiro, vol. 60, n’ 2, 2017 
Leonardo Avritzer e Marjorie Marona

Quadro 1

Comparação da Pena Aplicada antes e depois dos Acordos de Delação Premiada no Âmbito da Operação Lava Jato

\begin{tabular}{|c|c|c|c|}
\hline Delator & Qualificação & $\begin{array}{c}\text { Antiga Pena } \\
\text { (antes da delação) }\end{array}$ & $\begin{array}{l}\text { Pena negociada } \\
\text { (após a delação) }\end{array}$ \\
\hline Alberto Youssef & Doleiro & 82 anos e 8 meses & 3 anos (regime fechado) \\
\hline $\begin{array}{l}\text { Augusto } \\
\text { Mendonça }\end{array}$ & $\begin{array}{c}\text { Executivo (Toyo } \\
\text { Setal) }\end{array}$ & 16 anos e 8 meses & 4 anos (regime aberto) \\
\hline Dalton Avancini & $\begin{array}{c}\text { Executivo } \\
\text { (Camargo Corrêa) }\end{array}$ & 15 anos e 10 meses & $\begin{array}{c}3 \text { anos e } 3 \text { meses } \\
(3 \text { meses em regime } \\
\text { fechado, com progressão) }\end{array}$ \\
\hline Eduardo Leite & $\begin{array}{c}\text { Executivo } \\
\text { (Camargo Corrêa) }\end{array}$ & 15 anos e 10 meses & $\begin{array}{c}3 \text { anos e } 3 \text { meses } \\
(3 \text { meses em regime } \\
\text { fechado, com progressão) }\end{array}$ \\
\hline Fernando Baiano & $\begin{array}{l}\text { Operador do } \\
\text { Esquema }\end{array}$ & $\begin{array}{c}16 \text { anos, } 1 \text { mês e } 10 \\
\text { dias }\end{array}$ & $\begin{array}{c}4 \text { anos } \\
(1 \text { ano em regime } \\
\text { fechado, com progressão) }\end{array}$ \\
\hline Julio Camargo & $\begin{array}{c}\text { Lobista } \\
\text { (Tovo Setal) }\end{array}$ & 26 anos & 5 anos (regime aberto) \\
\hline Mario Goes & Lobista & 18 anos e 4 meses & $\begin{array}{l}3 \text { anos, } 5 \text { meses e } 25 \text { dias } \\
\text { ( } 25 \text { dias em regime } \\
\text { fechado, com progressão) }\end{array}$ \\
\hline Nestor Cerveró & $\begin{array}{c}\text { Burocrata } \\
\text { (Ex-diretor } \\
\text { internacional da } \\
\text { Petrobras) }\end{array}$ & $\begin{array}{c}17 \text { anos, } 3 \text { meses e } \\
10 \text { dias }\end{array}$ & $\begin{array}{l}3 \text { anos } \\
\text { (regime fechado e prisão } \\
\text { domiciliar e prisão } \\
\text { domiciliar) }\end{array}$ \\
\hline $\begin{array}{l}\text { Paulo Roberto } \\
\text { Costa }\end{array}$ & $\begin{array}{c}\text { Burocrata } \\
\text { (Ex-diretor de } \\
\text { abastecimento da } \\
\text { Petrobras) }\end{array}$ & 39 anos e 5 meses & $\begin{array}{c}2 \text { anos e } 6 \text { meses } \\
\text { (6 meses em regime } \\
\text { fechado, com progressão) }\end{array}$ \\
\hline Pedro Barusco & $\begin{array}{c}\text { Burocrata } \\
\text { (Ex-gerente da } \\
\text { Petrobras) } \\
\end{array}$ & 18 anos e 4 meses & $\begin{array}{l}2 \text { anos (regime } \\
\text { semiaberto) }\end{array}$ \\
\hline Rafael Ângulo & $\begin{array}{c}\text { Doleiro } \\
\text { (Funcionário de } \\
\text { Youssef) }\end{array}$ & 6 anos e 8 meses & $\begin{array}{l}2 \text { anos (regime } \\
\text { semiaberto) }\end{array}$ \\
\hline João Procópio & $\begin{array}{c}\text { Doleiro } \\
\text { (Funcionário de } \\
\text { Youssef) }\end{array}$ & 3 anos & $\begin{array}{l}2 \text { anos e } 6 \text { meses } \\
\text { (prisão domiciliar) }\end{array}$ \\
\hline
\end{tabular}

Fonte: Folha de S. Paulo, a partir dos dados disponibilizados pela Justiça Federal, ao final de $2015^{34}$. 
Nesse cenário, é possível perceber a enorme complacência com que são tratados os atores envolvidos no esquema, em nível operacional leia-se burocratas e empresários - considerando a extensa redução das penas daqueles que realizaram acordo de delação premiada: de 283 anos e 9 meses para 6 anos e 11 meses de reclusão, somados. Antevê-se uma estratégia de politização seletiva da Operação Lava Jato, declarada, aliás, pelo Procurador da República, Deltan Dallagnol, em entrevista à Folha de S. Paulo: "Nos acordos de colaboração, o princípio é de que se troca um peixe por um cardume, ou um peixe pequeno por um peixe grande" - leia-se políticos ligados ao governo e, até esse ponto, ao Partido dos Trabalhadores.

Associam-se a isso esforços de construção jurisprudencial que tendem a criminalizar a atividade política, algumas vezes pela importação de concepções teóricas constituídas em contextos absolutamente díspares do brasileiro, algumas vezes pelo puro e simples desrespeito aos princípios constitucionais e legislação vigente. Recentemente, o ex-presidente Luiz Inácio Lula da Silva foi conduzido coercitivamente para prestar depoimento no âmbito da Operação Lava Jato, sem que houvesse qualquer intimação prévia e, tampouco, descumprimento ou negativa em atendê-la, em uma clara violação não apenas da Constituição de 1988, como também da legislação penal. A condução coercitiva, assim como a associação da prisão preventiva ou temporária aos acordos de colaboração (delação premiada) são instrumentos jurídicos mobilizados de forma recorrente no âmbito da Operação Lava Jato.

\section{Quadro 2}

Medidas Judiciais Coercitivas na Lava Jato

(Março/2014-Março/2016)

\begin{tabular}{|c|c|c|c|c|c|}
\hline \multirow{3}{*}{$\begin{array}{c}\text { Mandados de } \\
\text { Busca e } \\
\text { Apreensão }\end{array}$} & \multirow{3}{*}{$\begin{array}{l}\text { Mandados de } \\
\text { Condução } \\
\text { Coercitiva }\end{array}$} & \multicolumn{2}{|c|}{ Mandados de Prisão } & \multicolumn{2}{|c|}{$\begin{array}{c}\text { Acordos de Colaboração } \\
\text { (Delação Premiada) }\end{array}$} \\
\hline & & Preventiva & Temporária & $\begin{array}{c}\text { Investigados } \\
\text { em Liberdade }\end{array}$ & $\begin{array}{c}\text { Investigados } \\
\text { Presos }\end{array}$ \\
\hline & & 64 & 69 & 35 & 14 \\
\hline 482 & 117 & \multicolumn{2}{|c|}{133} & \multicolumn{2}{|c|}{49} \\
\hline
\end{tabular}

Fonte: Elaboração própria, a partir dos dados disponibilizados pela Polícia Federal, atualizados até $4 / 3 / 2016^{35}$.

A recorrente associação entre a delação premiada e a prisão preventiva é exemplar, nesse sentido. Em inúmeras ocasiões em que a delação premiada se perfectibilizou, no âmbito da Operação Lava Jato, os delato-

DADOS - Revista de Ciências Sociais, Rio de Janeiro, vol. 60, nº 2, 2017 
res encontravam-se presos preventivamente, tendo sua liberdade concedida logo após a concretização do acordo, o que fere, frontalmente, o requisito da voluntariedade e afronta o Código de Processo Penal (art. 312), que determina que cidadãos só podem ser presos se houver risco à ordem pública e econômica, para a instrução criminal ou para a aplicação da lei penal, mas jamais para obtenção de confissão ou acordo de delação. Atesta-se aí, o claro desvio de função na aplicação da prisão preventiva.

Vale a pena mencionar, ainda, uma mudança de postura do próprio Supremo Tribunal Federal (STF), que se num primeiro momento de constituição desse cenário institucional no campo da judicialização da política assumiu determinada articulação com o Ministério da Justiça para restabelecer os parâmetros desejáveis de controle político, posto que compatíveis com os auspícios democráticos passou, gradativamente, a isentar-se de tal mediação. Destaca-se, aqui, a decisão do Plenário do Supremo Tribunal Federal ao aprovar, em 2008, no âmbito das discussões em torno dos desdobramentos da Operação Satiagraha ${ }^{36}$, a Súmula Vinculante no 11, que determinava a excepcionalidade do uso de algemas na condução dos presos. Naquela ocasião, o então presidente do STF, ministro Gilmar Mendes, declarou que a referida súmula tinha basicamente o objetivo de evitar o uso de algemas para exposição pública do preso, denunciando o abuso dos métodos utilizados pelos agentes da Política Federal na condução da Operação Satiagraha, particularmente o que chamou de "espetacularização das prisões" ${ }^{37}$.

OSTF, de fato, fortaleceu sua posição no sistema de divisão de poderes instalado no Brasil, particularmente a partir da Reforma do Judiciário (EC 45/04) que, dentre outras alterações, introduziu o instituto da Súmula Vinculante, com o intuito de pacificar a discussão de questões examinadas nas instâncias inferiores do Judiciário, ampliando a potência da jurisprudência formada pelo Supremo Tribunal Federal. Nesse cenário, a Corte foi muitas vezes acusada de tomar para si algumas prerrogativas do Congresso Nacional, como no caso da votação da cláusula de barreira (RE 635739) e da fidelidade partidária (ADI 5081/DF), mas, particularmente, a partir do julgamento da Ação Penal 470 observou-se uma mudança expressiva de postura do STF, em relação às garantias inscritas no direito penal e processual penal e também em face da sua competência em julgamentos criminais que envolvem o controle e combate à corrupção. 
O Supremo Tribunal Federal estendeu a prerrogativa de foro privilegiado aos 38 réus do processo que ficou conhecido como "mensalão", ainda que apenas três deles tivessem esse direito, por serem parlamentares, considerando que as acusações estavam ligadas ao mesmo fato, $o$ que justificaria o julgamento simultâneo, pela Corte, de todos eles. No caso da Operação Lava Jato, o ministro Teori Zavascki determinou o desmembramento do Inquérito (INQ) 3.989, instaurado para investigar o suposto envolvimento de políticos com foro privilegiado, em março de 2015, a partir das primeiras delações premiadas da Operação, mas manteve investigados sem foro privilegiado no âmbito da Suprema Corte. Posteriormente, o Plenário do STF decidiu desmembrar o inquérito 4.130, que investiga supostas condutas da senadora Gleise Hoffmann (PT-PR) em fatos associados às investigações da Operação Lava Jato, mas não relativos à corrupção na Petrobras, a fim de que a investigação prossiga no STF tão somente em relação à senadora. Em relação aos demais, entendeu pela remessa dos autos à Justiça Federal de São Paulo, onde a maior parte dos fatos denunciados teria ocorrido.

Ademais, inovações interpretativas que a Corte realizou no âmbito do julgamento da Ação Penal 470, particularmente pela aplicação da "teoria do domínio do fato" ${ }^{\prime 38}$, permitiram que se fundamentasse a responsabilidade de pessoas em posições de comando dentro de hierarquias, ainda que diante de um quadro de ausência de prova em relação a ações e omissões concretas de pessoas da cúpula diretiva. Vale lembrar que o expediente no STF é o único que apura o crime de formação de quadrilha, e esta é a ideia desde o início da Operação: analisar os esquemas de desvios de contratos da Petrobras e de outras estatais do ponto de vista da formação de uma organização criminosa ${ }^{39}$.

\section{NOTAS FINAIS}

Ao final de todo este processo pode-se afirmar, com segurança, que se constituiu a plena autonomia operacional das instituições judiciárias de controle no país, a qual tensiona, contudo, as instituições formadas pela soberania popular, contrariando tanto os preceitos republicanos de soberania (Rosanvallon, 2010) quanto os preceitos madsonianos de divisão dos poderes (Madison et al., 1993) ${ }^{40}$. A maneira como a corrupção está sendo combatida pela atuação combinada da Polícia Federal, do Ministério Público e do Poder Judiciário, considerando, especialmente, o padrão que estabeleceu com a Operação Lava Jato, implica em

DADOS - Revista de Ciências Sociais, Rio de Janeiro, vol. 60, n’ 2, 2017 


\section{Leonardo Avritzer e Marjorie Marona}

fortes questionamentos tanto da soberania quanto dos princípios de divisão de poderes.

Todos estes fatos parecem apontar na direção de um poder judiciário que, em articulação com outras instituições judiciárias, exorbita da autonomia concedida pelo quadro constitucional constituído em 1988, e avança para o campo de um pretorianismo jurídico. Assim, temos a afirmação de uma representação não soberana do interesse público por parte das instituições judiciárias de controle. O maior exemplo desta ideia distorcida de interesse público foi, mais uma vez, oferecida pelo juiz Sérgio Moro ao contrapor interesse público e legalidade no vazamento de gravações obtidas de modo ilegal na operação Lava Jato ${ }^{41}$.

Esta representação é problemática porque opera a passagem de uma defesa genérica do interesse público, que já continha fortes elementos antissoberanos, para um ataque político seletivo contra a soberania que perdeu até mesmo a mediação republicana do interesse público.

(Recebido para publicação em maio de 2016)

(Reapresentado em fevereiro de 2017)

(Aprovado para publicação em abril de 2017) 
A Tensão entre Soberania e Instituições de Controle na Democracia Brasileira

\section{NOTAS}

1. Temos em mente aqui o índice de democracia da revista Economist, assim como trabalhos de cunho acadêmico sobre a qualidade da democracia feitos por Morlino (2015). Vide https://en.wikipedia.org/wiki/Democracy_Index\#Democracy_index_by_region.

2. O Partido da Social Democracia Brasileira (PSDB), partido do candidato derrotado nas últimas eleições presidenciais, Aécio Neves, ingressou, em outubro de 2014, com quatro ações junto ao TSE contra a eleição da chapa de Dilma Rousseff e Michel Temer. Imediatamente após a divulgação do resultado do pleito, o PSDB requereu um pedido de auditoria especial dos resultados da eleição presidencial. Momentos antes do início da cerimônia de diplomação de Dilma Rousseff (Partido dos Trabalhadores - PT), o PSDB pediu ao TSE a cassação do registro de candidatura da presidente reeleita e de seu vice, Michel Temer (Partido do Movimento Democrático Brasileiro-PMDB), solicitando que o tribunal diplomasse Aécio Neves e Aloysio Nunes para os cargos de presidente e vice-presidente da República, respectivamente. Posteriormente, em janeiro de 2015 uma nova investida judicial, visando à impugnação do mandato de Dilma Rousseff (PT) e seu vice Michel Temer (PMDB), sob acusação de abuso de poder econômico, uso de estruturas públicas para promover a campanha e recursos oriundos de corrupção no financiamento, foi protagonizada pelo PSDB. Por ordem do então presidente do TSE, ministro Dias Toffoli, as quatro ações foram reunidas sob a relatoria da Corregedoria-Geral da Justiça Eleitoral. Em caso de uma condenação, como Dilma Rousseff já foi afastada do cargo, o atual presidente, Michel Temer, é quem poderia estar sujeito à perda de mandato. Até o momento não há decisão definitiva do TSE.

3. Essa foi uma medida que desatrelou da arrecadação grande parte dos recursos públicos que possuíam destinação específica. Iniciada no governo Itamar Franco, em 1994, através da Emenda Constitucional de Revisão 01/94, sob o nome de Fundo Social de Emergência (FSE), desde então, a DRU vem sendo renovada e sua sistemática aperfeiçoada, tendo sido criada no seu atual formato, pela Emenda Constitucional 27/00, a qual vem sendo sucessivamente prorrogada. Essa foi uma medida fundamental para o equilíbrio das contas públicas, ainda em 1994.

4. O conceito de soberania aqui utilizado segue a teoria política do século XVII e XVIII, tal como ele foi originalmente empregado para delimitar a influência de potências estrangeiras sobre o estado nacional, o termo foi progressivamente migrando para a teoria democrática (Held, 1987) na medida em que a soberania passou a ser entendida como a primazia dos cidadãos em um determinado território. Desse modo, a ideia de soberania passou a dizer respeito a um modo de governar ou a um modo de gerir as relações entre o governo e a população (Jackson, 2007). É nessa intersecção que se situam as relações entre as instituições democráticas e as instituições de controle. Existe, hoje, um forte movimento de deslocamento da legitimidade democrática, que altera as relações entre as instituições resultantes da soberania popular, isto é, as instituições constituídas pelo voto, e as instituições de controle (Rosanvallón, 2009).

5. Alguns dentre os mais importantes movimentos da sociedade civil - vinculados à saúde e aos movimentos de reforma urbana - e relevantes atores sociais, como a CUT (Central Única de Trabalhadores) ou o MST (Movimento dos Trabalhadores Sem-Terra) se juntaram à campanha por emendas populares (Whitaker et al., 1989).

DADOS - Revista de Ciências Sociais, Rio de Janeiro, vol. 60, n² 2, 2017 


\section{Leonardo Avritzer e Marjorie Marona}

6. É necessário ter em conta que em um cenário de "radicalização do princípio da igualdade" e "vocação expansiva do princípio democrático" implicou em uma "crescente institucionalização do direito na vida social" e não apenas transformou o cidadão e sujeito de direito, como também, fez emergir novos detentores de direitos, ampliando o próprio conceito de cidadania. É nessa perspectiva que se defende, nesse artigo, que o Ministério Público, por meio da defesa dos direitos sociais, difusos e coletivos, passou a mediar a cidadania no Brasil nos anos 1990.

7. Adicionalmente, nos últimos anos, registrou-se um aprofundamento dessa dimensão da democracia brasileira, não apenas pela criação de novas instituições de controle, tal como a Controladoria Geral da União (CGU), mas também pela ampliação das prerrogativas de algumas já existentes - a exemplo do que ocorreu com o Tribunal de Contas da União (TCU) - ou pela completa revolução institucional, conforme ocorrido com a Polícia Federal (Arantes, 2015), na linha de um incrementalismo institucional (Filgueiras e Aranha, 2011).

8. Para uma breve reflexão sobre a questão na tradição constitucional norte-americana, debatendo a atual situação política da Argentina, ver Gargarella (2015).

9. O conceito de interesse público é central para a discussão acerca da corrupção, pois o significado dessa está atrelado à definição daquele. Entendemos por interesse público a ideia republicana de interesses comuns aos cidadãos. Esta ideia permitiu uma posterior diferenciação entre direito público e direito privado que está sim articulada com a ideia de um poder político eleito pela maioria. Considera-se aqui que o primado legal do interesse público, a demandar a compatibilização, regulação e mesmo contenção dos interesses privados, deve ser cotejado com a necessária mediação da ação democrática majoritária, a se expressar em todo o sistema legal e de instituições, como o único modo de produzir sínteses legitimadas em um quadro de pluralismo valorativo e de conflito de interesses (Guimarães, 2008).

10. A ideia comum de corrupção corresponde a um conceito não jurídico, ou seja, que não deriva de normas jurídicas nem se refere a uma figura jurídica particular. No sistema jurídico brasileiro, existem apenas as figuras jurídicas da corrupção passiva e ativa (artigos 317 e 333 do Código Penal) e, ainda, a da corrupção de menores (art. 218 do Código Penal). Contudo, o sentido atribuído à corrupção pelas pessoas em geral, e pelos meios de comunicação, em particular, é mais amplo. Trata-se de um sentidoou conjunto de sentidos - que advém de um conceito construído a partir de diversas disciplinas das ciências sociais. Esse sentido mais amplo corresponde à hipótese de mau uso da função pública com vistas à obtenção de uma vantagem particular (Bobbio, 1988).

11. O Ministério Público (ao lado dos Tribunais de Contas, do Poder Legislativo, e da Polícia Judiciária, por exemplo) pode optar por um entre dois instrumentos para proceder a apurações de atos de improbidade administrativa: inquérito civil/penal público ou procedimento administrativo preparatório. As conclusões das apurações realizadas pela administração pública ou pela polícia judiciária não condicionam a atuação do Ministério Público, que ostenta, portanto, enorme ingerência no emaranhado de estágios que constituem a fase apuratória das condutas que conformam o fenômeno da corrupção no Brasil.

12. A Assembleia Nacional Constituinte foi marcada pela participação alargada e inclusão de diversos setores organizados da sociedade civil, o que permitiu que o Ministério Público, através de seu Conselho Nacional (Conamp) fosse bastante ativo no pro- 
cesso de redação da nova Constituição. Segundo Coslovsky (2016) o Conamp, que vinha se mobilizando nas décadas anteriores para formar associações de promotores e procuradores viu na Assembleia Nacional Constituinte uma oportunidade para propor uma carreira especial, tendo demandado, ainda no final de 1986, autonomia organizacional (incluída autonomia orçamentária) para o Ministério Público.

13. Trata-se de um instrumento jurídico com força de título extrajudicial, por meio do qual se faculta a suspensão de ações de responsabilidade diante do compromisso assumido pelo causador do dano em repará-lo e/ou em cessar as ações que o causam ou causaram.

14. É importante notar que a via criminal, que impõe penas privativas de liberdade, além da perda do cargo e pagamento de multa, importa no reconhecimento de algumas garantias processuais. Particularmente, o réu que goza de prerrogativa de foro especial, será julgado, obrigatoriamente, por um tribunal.

15. O sistema penal brasileiro está estruturado, fundamentalmente, sob o capítulo dos direitos e garantias individuais da Constituição de 1988, o Código Penal Brasileiro (CPB) e o Código de Processo Penal (CPP) e funciona a partir do princípio da presunção de inocência (CRFB/88, art. 5ํㅡ, XVII) e do devido processo legal (CRFB/88, art. 5 으, LIV e LV). A mais significativa crítica dirigida ao modo como a justiça criminal funciona no Brasil diz respeito à sua falta de celeridade - particularmente pelo infinito número de recursos - mas também à sua seletividade - representada pelo instituto do foro privilegiado e expressa pelo grande rol de "clientes preferidos" do sistema (os analfabetos, os negros, os favelados, pobres, marginalizados), o que gera uma sensação de impunidade, particularmente em face de políticos e empresários envolvidos em casos graves de crimes contra a Administração Pública. Voltaremos a esse ponto adiante. Ver: Levantamento Nacional de Informações Penitenciárias do Ministério da Justiça de 2014. Disponível em http://www.justica.gov.br/seus-direitos/politica-penal/documentos/infopen_dez14.pdf>. Acessado em 29/1/2017.

16. De fato, o orçamento da Polícia Federal e o seu contingente cresceram significativamente nos últimos anos, o que impactou na sua atuação de controle da administração pública, particularmente por meio da investigação e persecução criminais da corrupção e do crime organizado.

17. A Polícia Federal é um órgão do Poder Executivo que, embora subordinado ao Ministério da Justiça, possui caráter permanente (não pode ser dissolvido por nenhum governo) e jurisdição nacional, competindo atuar nos casos de crimes contra a ordem política e social, assim como proteger os bens, serviços e interesses da União, realizando ações de prevenção e repressão do tráfico de drogas e contrabando, reservando-se também à sua atuação os crimes de dimensão internacional, tudo segundo dispõe o art. 114 da CRFB/ 88.

18. Outros órgãos também se unem, eventualmente, aos trabalhos de investigação e responsabilização dos acusados, tais como a Receita Federal, a Controladoria Geral da União, por exemplo.

19. No entanto, pesquisa do Centro do Interesse Público (CRIP) da Universidade Federal de Minas Gerais (UFMG), realizada entre 2008 e 2009, já apontava a percepção da população de que havia abusos por parte da Polícia Federal na condução das investigações. Relatórios de pesquisa disponíveis em <http://democraciaejustica.org/ cienciapolitica3/node/156>. Último acesso em 8/3/2016. Coube, naquele momento

DADOS - Revista de Ciências Sociais, Rio de Janeiro, vol. 60, n² 2, 2017 


\section{Leonardo Avritzer e Marjorie Marona}

original, à instância política - particularmente ao Ministério da Justiça - e à instância judicial - particularmente ao Supremo Tribunal Federal (STF) - mitigá-los, o que pode ser observado pelos desdobramentos da Operação Satiagraha. Também a grande mídia, se posicionava de forma bastante crítica diante das investidas investigativas da Polícia Federal e do Ministério Público, desde o início dos anos 2000. Em editorial (15/8/2000), o jornal O Globo, em face da atuação do Procurador da República Luiz Francisco de Souza, que implicava uma série de políticos ligados ao então presidente da república, Fernando Henrique Cardoso, chamava a atenção para os perigos da "ofensiva contra a imagem do próprio presidente da República", condenando as ações que "confundissem indícios com provas, possibilidades com certezas e, acima de tudo, desejos com fatos" e pontuando que "o interesse público pede principalmente algo bastante elementar: que guardem suas denúncias para o fim do processo investigatório e não as alardeiem no início, quando são ainda suspeitas". Disponível em <http: / /acervo.oglobo.globo.com/busca/?busca=tese+da\#podrid\%C3\%A3o $>$. Acesso em 5/3/2016.

20. A Operação Lava Jato é uma investigação em andamento no Brasil, cuja fase ostensiva foi deflagrada em março de 2014, pelo cumprimento de mais de cem mandados de busca e apreensão, de prisão temporária, de prisão preventiva e de condução coercitiva, visando apurar um esquema que - estima-se - movimentou de 10 a 20 bilhões de reais em propina. A Polícia Federal investiga crimes de corrupção ativa e passiva, gestão fraudulenta, lavagem de dinheiro, organização criminosa, obstrução da justiça, operação fraudulenta de câmbio e recebimento de vantagem indevida. De acordo com investigações e delações recebidas pela força-tarefa da Lava Jato, estão envolvidos os maiores partidos do Brasil (Partido Progressista - PP, PT e PMDB), além de empresários e outros políticos de diversos partidos, como o PSDB. Sobre a Operação Lava Jato: <https://pt.wikipedia.org/wiki/Opera\%C3\%A7\%C3\%A3o_Lava_ Jato $>$. Último acesso em 29/01/17.

21. O devido processo legal (due process of law) é um princípio legal proveniente do direito anglo-saxão que determina que todo ato praticado por autoridade, para ser considerado válido, eficaz e completo, deve seguir as etapas previstas em lei. No Brasil, os incisos LIV e LV do art. 5으 da CRFB / 88 expressam a essência do princípio e seu corolário, respectivamente, determinando que, "ninguém será privado da liberdade ou de seus bens sem o devido processo legal" e que "aos litigantes em processo judicial e administrativo, e aos acusados em geral, serão assegurados o contraditório e a ampla defesa, com os meios de recurso a ela inerentes".

22. Na íntegra, assim decidiu, liminarmente, o então Presidente do STF, Ministro Gilmar Mendes: "Para que sejam suspensos os efeitos do decreto de prisão preventiva de DANIEL VALENTE DANTAS, expedido pelo Juízo da 6- Vara Criminal Federal da Seção Judiciária de São Paulo nos autos do processo no 2008.61.81.009733-3. Expeça-se alvará de soltura. Encaminhem-se cópias desta decisão à Presidência do Tribunal Regional Federal da 3aㅡ Região, à Corregedoria-Geral da Justiça Federal da $3^{\text {a }}$ Região, ao Conselho da Justiça Federal e à Corregedoria Nacional de Justiça. Abra-se vista dos autos ao Procurador-Geral da República (RI/STF, art. 192). Disponível em http:/ / www.stf.jus.br/portal/processo/verProcessoAndamento.asp?incidente $=2624121$. Último Acesso em 29/01/17.

23. Recentemente o TRF da $4^{\mathrm{a}}$ Região se manifestou no sentido de que a complexidade da Operação Lava-Jato permite a relativização do prazo para o encerramento do 
Inquérito Policial (HC 5028376-34.2015.4.04.0000). O Supremo Tribunal Federal (STF), talvez na única correção que tenha imposto às ações do juiz Sérgio Moro na condução judicial da Operação Lava-Jato, o fez de forma bastante branda. O então Ministro Relator Teori Zavascki anulou a validade jurídica da escuta telefônica que interceptou conversa do ex-presidente Lula com a presidente afastada Dilma Rousseff, considerando que Moro não tinha competência para avaliar o material, além de considerar irregular a divulgação das conversas. Moro encaminhou ofício aoSTF, desculpando-se pelo ocorrido e a questão e resolveu nesses termos, sem qualquer medida disciplinar. Tão pouco o Ministério da Justiça tem exercido qualquer constrangimento sobre a atuação da Polícia Federal. Vale a pena mencionar que desde 2014, com a aprovação da Medida Provisória 657/14, o cargo de diretor-geral da Polícia Federal tornou-se privativo de delegado da classe especial (último nível da carreira). Até então, o provimento desse cargo era de livre nomeação e exoneração pela Presidência da República.

24. O termo foi cunhado por Tate e Vallinder, na clássica obra The Global Expansion of Judicial Power (1995).

25. A delação premiada é um instrumento jurídico moldado sob os discursos da ineficiência estatal, de viés altamente prático, cunhado para dar respostas às demandas da sociedade no campo da segurança pública. Na prática, a delação premiada possibilita algum benefício processual ou penal (redução de pena, perdão judicial, a aplicação de regime penitenciário brando, etc.) ao acusado (ou indiciado) que contribui com informações sobre a prática delitiva, particularmente apontando outros envolvidos, para fazer cessar a conduta criminosa. Daí se conclui que a suposta vantagem que a delação premiada enseja ao criminoso resta justificada pelas informações prestadas por ele, as quais devem efetivamente contribuir para fazer cessar a conduta criminosa. A dimensão estratégica, associada ao instituto, não desaparece, contudo, em razão disso, pois ao acusado resta sempre a possibilidade de aceitar ou não a proposta de acordo de delação premiada que a autoridade eventualmente lhe ofereça e também determinar os termos e a extensão das informações que vai prestar.

26. Como disse Thomas Jefferson, "eu considero o julgamento por júri como a única âncora imaginada pelo homem, pela qual um governo pode ser mantido aos princípios de sua constituição".

27. A Sexta Emenda garante que "em todos os processos penais, o acusado gozará do direito a um julgamento rápido e público, por um júri imparcial", contando com a assistência de um advogado, que pode confrontar e interrogar seus acusadores e apresentar provas em nome do acusado, que só pode ser condenado se um júri imparcial unanimemente entender pela sua culpa, afirmando, publicamente, seu veredito.

28. Em média, 95\% dos casos admitidos para julgamento de crimes graves nos EUA (considerando tanto o sistema federal quanto o sistema estadual) são resolvidos por plea bargain, em negociações que determinam os termos da confissão e a extensão das sentenças. Essa é uma realidade que começou a se desenhar depois da Guerra Civil, particularmente pelo aumento da criminalidade a desafiar a eficiência do sistema de justiça. A plea bargain oferecia uma alternativa: ao se declarar culpado de crimes menores, em troca do não processamento de crimes mais graves, os acusados tinham a opção de reduzir seu tempo de prisão, enquanto a acusação, por sua vez, resolvia o caso sem sobrecarregar o sistema de justiça. A Suprema Corte Norte-Americana, favorável ao sistema, compreende-o como um exercício de negociação contratual entre

DADOS - Revista de Ciências Sociais, Rio de Janeiro, vol. 60, n² 2, 2017 


\section{Leonardo Avritzer e Marjorie Marona}

agentes independentes (o promotor e o advogado) que amplia a eficácia do sistema criminal. Mais uma vez como reação ao aumento das taxas de criminalidade, nos anos de 1970 e 1980 as legislações estaduais e federais aumentaram enormemente as penas por violações criminais graves, e, além disso, em resposta àquilo que se considerava uma tendência à leniência por parte de muitos juízes, observou-se, nos 37 estados onde os juízes eram eleitos, que muitos daqueles considerados "suaves" foram derrotados e substituídos por magistrados tidos como "duros com o crime". Houve alterações legislativas no nível federal a enrijecer e ampliar a severidade do sistema de dosimetria das penas, o que ampliou o poder dos promotores na negociação das plea bargains, extinguindo virtualmente os julgamentos por júri em casos criminais federais: enquanto em 1980, 19\% de todos os réus federais foram a julgamento, em 2000 o percentual tinha diminuído para menos de $6 \%$ e em 2010 para menos de $3 \%$ patamar que permanece desde então. Ver: Rakoff (2014).

29. Nossos legisladores já aprovaram de 1940 (data do Código Penal) até 2015 mais de 150 leis penais, sendo quase $80 \%$ delas mais duras, mais severas. No entanto, a criminalidade continua crescendo: o número de assassinatos de 1980 (11 para cada $100 \mathrm{mil}$ pessoas) subiu, em 2013, para 29/100 mil (veja DataSus).

30. A participação do magistrado na negociação de culpa é proibida nos tribunais federais norte-americanos sob o argumento de que haveria risco de comprometimento de sua objetividade no caso de não haver acordo. Por razões semelhantes, muitos juízes federais recusam-se a tomar parte em negociações de resolução de litígios civis, embora, ao contrário da situação de barganha criminal, não haja impedimento legal para fazê-lo.

31. Observe-se, particularmente, a nova redação do artigo 201 do Código de Processo Penal dada pela Lei no 11.690 de 2008, na parte em que impõe ao juiz o dever de preservação da intimidade, vida privada, honra e imagem do ofendido, via segredo de justiça.

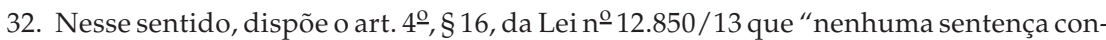
denatória será proferida com fundamento apenas nas declarações de agente colaborador".

33. Recentemente, o STF se manifestou no sentido de que os acordos de delação premiada não atraem, automaticamente, a competência do juízo que os homologa referente a todos os crimes relatados, mas apenas quando os fatos apontados no inquérito estejam ligados às investigações principais. Contudo, segundo o princípio da unidade do processo e do julgamento, desdobrado na previsão da prevenção do juízo para determinação da competência (CPP, art. 83), o juiz que presidiu o inquérito deverá atuar na fase judicial.

34. Disponível em <http://economia.terra.com.br/pena-de-condenados-delatores-da-lava-jato-cai-de-283-para-7-anos-diz-folha,4432df60f91a44f45547686c51d 03b7af7aj9ilp.html> Último acesso em 8/3/2016.

35. Disponível em <http://lavajato.mpf.mp.br/atuacao-na-1a-instancia/resultados /a-lava-jato-em-numeros-1>. Último acesso em 9/3/2016.

36. A Súmula Vinculante $\mathrm{n}$ ำ 11 foi editada um mês depois da prisão de um dos alvos da Operação Satiagraha, o banqueiro Daniel Dantas, que, foi algemado até a carceragem da Polícia Federal. À época, o ministro Gilmar Mendes, então presidente do Supremo Tribunal Federal, determinou sua soltura, sob a alegação de que não houve 
justificativa para o uso de algemas, o que o tornava ilegal. Outro alvo da Operação Satiagraha, o banqueiro Salvatore Cacciola, também obteve Habeas Corpus por ter sido algemado de maneira ilegal.

37. Vide <http://zh.clicrbs.com.br/rs/noticia/2008/07/gilmar-mendes-critica-metodos-da-pf-na-operacao-satiagraha-2032682.html>. Último acesso em 28/04/16.

38. A teoria do domínio do fato ganhou projeção em 1963, com o trabalho do jurista alemão Claus Roxin, pela alteração que provocou na jurisprudência alemã, que até então tomava como partícipe - e não como autor - aquele que ocupava posição de comando, planejava e dava ordens para a execução de um crime. A partir da teoria do domínio do fato tornou-se possível condenar um governante ou líder de um grupo, mesmo que ele não fosse o responsável direto pelo delito. Contudo, conforme destacou o próprio Roxin não bastavam indícios, para tanto; eram necessárias provas.

39. Essa nova postura vem sendo reafirmada pela Corte quejá se manifestou sobre a possibilidade de prisão em segunda instância (HC 126292) e a consideração de que inquéritos e ações penais em curso podem ser considerados como maus antecedentes para a dosimetria das penas, em temerosa tendência de afirmação de um estado penal, que avança, agora, pelos domínios da atividade política, pela via da espetacularização do processo penal (Casara, 2015).

40. Vale a pena observar aqui que o princípio federalista é que nenhum poder tente usurpar um poder ou prerrogativa do outro.

41. Vide Despacho/Decisão proferido em 17 de março de 2016 nos autos do Pedido de Quebra de Sigilo de Dados e / ou Telefônico no5006205-98.2016.4.04.7000/PR. Disponível em <http://www1.folha.uol.com.br/poder/2016/03/1750991-moro-defende-legalidade-de-grampo-e-traca-paralelo-entre-dilma-e-nixon.shtml $>$. Acessado em 25/4/2016. 


\section{Leonardo Avritzer e Marjorie Marona}

\section{REFERÊNCIAS BIBLIOGRÁFICAS}

ABERS, Rebecca. (2000), Inventing Local Democracy: Grassroots Politics in Brazil. Boulder, CO, Lynne Rienner Publishers.

ALMEIDA, Debora Rezende de. (2010), “Metamorfose da Representação Política: Lições Práticas dos Conselhos de Saúde no Brasil”, in L. Avritzer (org.), A Dinâmica da Participação Local no Brasil. São Paulo, Cortez.

(2015), Representação para além das Eleições: Repensando as Fronteiras entre Estado e Sociedade. Jundiaí, Paco Editorial.

ALMEIDA, Frederico Normanha Ribeiro de. (2010), A Nobreza Togada: As Elites Jurídicas e a Política da Justiça no Brasil. Tese (Doutorado em Ciência Política). Programa de Pós-Graduação em Ciência Política da Universidade de São Paulo, São Paulo.

ARANTES, Rogério B. (2002), Ministério Público e Política no Brasil. São Paulo, Educ/Sumaré.

. (2007), Ministério Público na Fronteira entre a Justiça e a Política. São Paulo, Procuradoria-Geral de Justiça em convênio com a Associação Paulista do Ministério Público, vol. 197, pp. 325-335.

. (2010), "The Federal Police and the Ministério Público", in T. Power; M. Taylor (orgs.), Corruption and Democracy in Brazil. Notre Dame, University of Notre Dame Press, pp. 184-217.

. (2011), "Polícia Federal e Construção Institucional", in L. Avritzer; F. Filgueiras (orgs.), Corrupção e Sistema Político no Brasil. Rio de Janeiro, Civilização Brasileira, pp. 99-132.

. (2012), “Ministério Público à Brasileira". Le Monde Diplomatique Brasil. São Paulo, 1 de junho. Disponível em: <http://www.diplomatique.org.br/artigo.php?id= 1194\#.VGod1eQDYuU>. Acessado em 5/12/2014.

. (2015), “Rendición de Cuentas y Pluralismo Estatal en Brasil: Ministerio Público y Policía Federal/Accountability and State Pluralism in Brazil: Public Ministry and Federal Police". Desacatos, № 49, p. 28.

AVRITZER, Leonardo. (2009), Democracy and the Public Space in Latin America. Princeton, Princeton University Press.

. (2015), “Autonomia do Judiciário versus Pretorianismo Jurídico-Midiático". Carta Maior, agosto. Disponível em <http://cartamaior.com.br/?/Editoria/Politica/Autonomia-do-judiciario-versus-pretorianismo-juridico-midiatico/4/34197>. Acessado em 22/11/2015.

(2016), Impasses da Democracia no Brasil. Rio de Janeiro, Civilização Brasileira.

BANCO MUNDIAL. (2013), Country Report. Washington.

BOBBIO, Norberto. (1988), Dicionário de Política. Brasília, UnB, pp. 291-293.

CAMPOS, Gabriel Silveira de Queirós. (2012), “Plea Bargaining e Justiça Criminal Consensual: Entre os Ideais de Funcionalidade e Garantismo". Custus Legis, Revista Eletrônica do Ministério Público Federal, pp. 1-26. Disponível em 
<http: / / www.prrj.mpf.mp.br/custoslegis / revista / 2012_Penal_Processo_Penal_Campos_Plea_Bargaining.pdf $>$. Acessado em 22/11/2015.

CARVALHO, Ernani; LEITÃO, Natália. (2010), “O Novo Desenho Institucional do Ministério Público e o Processo de Judicialização da Política". Revista Direito GV, ano 6, no 2, pp. 399-422.

CASARA, Rubens R. R. (2015), Processo Penal do Espetáculo: Ensaios sobre o Poder Penal, a Dogmática e o Autoritarismo na Sociedade Brasileira. Rio de Janeiro, Empório do Direito.

CÔRTES, Soraya M. Vargas. (2005), “Arcabouço Histórico-institucional e a Conformação de Conselhos Municipais de Políticas Públicas". Educar em Revista, no25, pp. 143-174.

CUNHA, Eleonora Schettini Martins et al. (2011), “Uma Estratégia Multidimensional de Avaliação dos Conselhos de Políticas: Dinâmica Deliberativa, Desenho Institucional e Fatores Exógenos", in R. R. Pires (org.), Efetividade das Instituições Participativas no Brasil: Estratégias de Avaliação. Brasília, Ipea, pp. 297-322.

FALCÃO, Joaquim. (2015), “Lava Jato Muda a Justiça e a Advocacia”. Folha de S. Paulo, Opinião, 31/7/2015. Disponível em: http://www1.folha.uol.com.br/opiniao/ 2015/07/1662597-lava-jato-muda-a-justica-e-a-advocacia.shtml.

FILGUEIRAS, Fernando; ARANHA, Ana Luiza Melo. (2011), “Controle da Corrupção e Burocracia da Linha de Frente: Regras, Discricionariedade e Reformas no Brasil". DADOS - Revista de Ciências Sociais, vol. 54, no 2, pp. 349-387.

GARGARELLA, Roberto. (2015), “Diálogo y Consenso, o Concesiones Penosas?”. El Clarin, Opinión, 30/11/2015. Disponível em: <http://www.clarin.com/opinion/ Controles_entre_poderes-Dialogo_inclusivo-Elitismo-Desigualdad-Corrupcion_ 0_1477052317.html>.

GUIMARÃES, Juarez. (2008), “Interesse Público”, in L. Avritzer et al. (orgs.), Corrupção: Ensaios e Críticas. Belo Horizonte, Editora UFMG, pp. 173-178.

HABERMAS, Jürgen. (1987), Teoría de la Acción Comunicativa. Madrid, Taurus.

HELD, David. (9187), Modelos de Democracia. Belo Horizonte, Paideia.

HUNTINGTON, Samuel. (1972), El Orden Político en las Sociedades en Cambio. Buenos Aires, Paidos.

JACKSON, Robert. (2007), Sovereignty: The Evolution of an Idea. Cambridge, Polity Press.

KERCHE, Fábio. (2007), “Autonomia e Discricionariedade do Ministério Público no Brasil”. DADOS - Revista de Ciências Sociais, vol. 50, no 2, pp. 259-279.

LAVALLE, Adrián; VERA, Ernesto Isunza. (2011), “A Trama da Crítica Democrática: Da Participação à Representação e à Accountability". Lua Nova, vol. 84, pp. 353-364.

LOPES JR., Aury. (2002), “Justiça Negociada: Utilitarismo Processual e Eficiência Antigarantista", in A. Wunderlich; S. Carvalho (orgs.), Diálogos sobre Justiça Dialogal. Rio de Janeiro, Lumen Juris, pp. 99-128.

. (2011), O Novo Regime Jurídico da Prisão Processual, Liberdade Provisória e Medidas Cautelares Diversas. Rio de Janeiro, Lumen Juris.

MADISON, James; HAMILTON, Alexander; JAY, John. (1993), Os Artigos Federalistas: 1787-1788. Trad. Maria Luiza X. de A. Borges. Rio de Janeiro, Nova Fronteira.

DADOS - Revista de Ciências Sociais, Rio de Janeiro, vol. 60, n² 2, 2017 


\section{Leonardo Avritzer e Marjorie Marona}

MARCHETTI, Vitor. (2013), Justiça e Competição Eleitoral. Santo André, UFABC.

MARONA, Marjorie. (2015), “Minientrevista”. Jornal O Tempo, 6/7/2015. Disponível em: <http://www.otempo.com.br/capa/pol\%C3\%ADtica/minientrevista-1.1065047>.

O’DONNELL, Guillermo. (1990), Análise do Autoritarismo Burocrático. Rio de Janeiro, Paz e Terra.

(1991), “Democracia Delegativa?". Novos Estudos, no 31. Disponível em: $<$ http://novosestudos.uol.com.br/v1/files/uploads/contents /65/20080624_democracia_delegativa.pdf $>$. Acessado em 30/11/2014.

. (1996), “Uma outra Institucionalização: América Latina e Alhures". Lua Nova, no 37, pp. 5-31.

. (1998), "Accountability Horizontal e Novas Poliarquias". Lua Nova, no 44, pp. 27-54.

MORLINO, Leonardo. (2015), Conferência proferida na Cátedra Brasileiro-Mexicana Guillermo O'Donnell. Faculdade de Ciências Econômicas/UFMG, 8 e 9 de junho.

POGREBINSCHI, Thamy. (2011), Judicialização ou Representação? Política, Direito e Democracia no Brasil. Rio de Janeiro, Elsevier Brasil.

RAKOFF, Jed S. (2014), "Why Innocent People Plead Guilty". The New York Review of Books, vol. 61, no 18.

ROSANVALLÓN, Pierre. (2009), La Legitimidad Democrática: Imparcialidad, Reflexividad, Proximidad. Buenos Aires, Manantial.

(2010), Por uma História do Político. São Paulo, Alameda Casa Editorial.

(2014), La Contre-Démocratie. La Politique à l'Âge de la Défiance. Paris, Seuil.

SADEK, Maria Tereza. (2009), Cidadania e ministério público. In SADEK, Maria Tereza. Justiça e cidadania no Brasil. Rio de Janeiro: Centro Edelstein, 2009. Disponível em (acesso em 30/11/2014): <http://static.scielo.org/scielobooks/rrwrz/pdf/sanches-9788579820175.pdf $>$.

SANTOS, Fabiano. (2013), "Por que a Criminalização da Política Interessa às Grandes Corporações?". Carta Maior Disponível em http://www.cartamaior.com.br/?/Editoria/Politica/Por-que-a-criminalizacao-da-politica-interessa-as-grandes-corporacoes-/4/29746. Acessado em 22/11/2015.

SCOTT, Robert; STUNTZ, William. (1992), "Plea Bargaining as Contract". The Yale Law Journal, vol. 101, no 8, pp. 1909-1968.

STRECK, Lênio Luiz. (2013), O Que É Isto - Decido Conforme Minha Consciência?. (4ạ ed. rev.). Porto Alegre, Livraria do Advogado Editora.

TATE, C. Neal; VALLINDER, Torbjörn. (1995), The Global Expansion of Judicial Power. New York, New York University Press.

TOUCHTON, Michael; WAMPLER, Brian. (2014), “Improving Social Well-being through New Democratic Institutions". Comparative Political Studies, vol. 47, no 10, pp. 1442-1469.

VAZ, Alexander Cambraia N. (2014), Capacidades Estatais para o Desenvolvimento: Entre a Burocratização e a Política como Elemento de Ação do Estado. Tese (Doutora- 
A Tensão entre Soberania e Instituições de Controle na Democracia Brasileira

do em Ciência Política), Programa de Pós-Graduação de Ciência Política, Faculdade de Filosofia e Ciências Humanas, Universidade Federal de Minas Gerais, Belo Horizonte.

VIANNA, Luiz Werneck et al. (1999), A Judicialização da Política e das Relações Sociais no Brasil. Rio de Janeiro, Renavan.

VIEIRA, Oscar Vilhena. (2008), "Supremocracy". Revista Direito GV, vol. 4, no 2, pp. 441-463.

WACQUANT, Loïc. (2001), Punir os Pobres: A Nova Gestão da Miséria nos Estados Unidos. Rio de Janeiro, Freitas Bastos.

WAMPLER, Brian. (2007), Participatory Budgeting in Brazil: Contestation, Cooperation, and Accountability. Pennsylvania, Penn State University Press.

. (2014), "Contentious Politics and Participatory Democracy in Brazil". Política E Sociedade, vol. 13, no 28, pp. 199-224.

WHITAKER, Francisco et al. (1989), Cidadão Constituinte: A Saga das Emendas Populares. Rio de Janeiro, Paz e Terra.

DADOS - Revista de Ciências Sociais, Rio de Janeiro, vol. 60, n² 2, 2017 
Leonardo Avritzer e Marjorie Marona

RESUMO

A Tensão entre Soberania e Instituições de Controle na Democracia Brasileira

O presente artigo procura mostrar de que modo o giro da accountability na democracia brasileira favoreceu o surgimento de inovações institucionais no sistema judicial, propiciando uma espécie de pretorianismo jurídico. Este, por sua vez, desembocou em um cenário de criminalização da atividade política que coloca em risco a democracia brasileira. Particularmente, a partir da análise da condução da Operação Lava Jato, os autores buscam demonstrar deslocamentos conceituais no campo da representação e do interesse público e a correlata tensão entre controle político e soberania que se estabelece como um dos principais desafios para a democracia brasileira atualmente, diante do tipo de protagonismo que o Poder Judiciário, o Ministério Público e a Polícia Federal assumiram na condução das estratégias de combate à corrupção por parte do Estado.

Palavras-chave: soberania; controle político; inovações participativas; pretorianismo judicial; corrupção

\section{ABSTRACT}

The Tension between Sovereignty and Institutions of Control in Brazilian Democracy

The following article seeks to demonstrate how the shift toward accountability to have permeated Brazilian democracy favored the emergence of institutional innovations in the judicial system, promoting a kind of legal Praetorianism. Such Praetorianism, in turn, led to a criminalization of political activities which has shaken the very foundations of Brazilian democracy itself. With a focus on analyzing the Operação Lava Jato [Operation Car Wash] scandal, the authors seek to demonstrate conceptual shifts in the field of representation and public interest. The resultant tension produced between political control and sovereignty is one of the main challenges currently faced by Brazilian democracy, in light of the leading role assumed by the Judiciary Branch, the Public Prosecutor, and the Federal Police in the State's employment of strategies to target corruption.

Keywords: sovereignty; political control; participatory innovations; legal Praetorianism; corruption 
RÉSUMÉ

La Tension entre Souveraineté et Institutions de Contrôle dans la Démocratie Brésilienne

Le présent article souhaite montrer de quelle manière la montée en puissance de l'accountability dans la démocratie brésilienne a favorisé l'éclosion d'innovations institutionnelles au sein du système judiciaire pour créer une sorte de prétorianisme juridique à la base d'une criminalisation croissante de l'activité politique mettant en péril la démocratie brésilienne. C'est en particulier à partir de l'analyse de l'Opération Lava Jato que les auteurs ont cherché à montrer les altérations conceptuelles intervenues dans le champ de la représentation et de l'intérêt public, et la tension conséquente entre contrôle et souveraineté qui se manifeste aujourd'hui comme l'un des principaux défis de la démocratie brésilienne. Il s'agit ainsi de mettre en lumière l'intense activité du Pouvoir judiciaire, du Ministère public et de la Police fédérale dans le cadre des stratégies de lutte contre la corruption adoptées par l'État.

Mots-clés: souveraineté; contrôle politique; innovations participatives; prétorianisme judiciaire; corruption

\section{RESUMEN}

La Tensión entre la Soberanía y los Organismos de Control en la Democracia Brasileña

El presente artículo pretende mostrar hasta qué punto el cambio de rumbo de la accountability en la democracia brasileña ha favorecido el surgimiento de innovaciones institucionales en el sistema judicial, propiciando una especie de pretorianismo jurídico que ha desembocado en un escenario de criminalización de la actividad política que pone en riesgo a la democracia brasileña. En concreto, a partir del análisis de la conducción de la Operación Lava Jato, los autores quieren demostrar la existencia de cambios conceptuales en el campo de la representación y del interés público, y la consecuente tensión entre control político y soberanía que se revela como uno de los principales desafíos actuales para la democracia brasileña, ante la clase de protagonismo que el Poder Judicial, el Ministerio Público y la Policía Federal han asumido en la conducción de las estrategias de lucha contra la corrupción por parte del Estado.

Palabras clave: soberanía; control político; innovaciones participativas; pretorianismo judicial; corrupción

DADOS - Revista de Ciências Sociais, Rio de Janeiro, vol. 60, n² 2, 2017 